\title{
Agrobacterium tumefaciens-mediated transformation of poinsettia, Euphorbia pulcherrima, with virus-derived hairpin RNA constructs confers resistance to Poinsettia mosaic virus
}

\author{
Jihong Liu Clarke $\cdot$ Carl Spetz $\cdot$ Sissel Haugslien • \\ Shaochen Xing • Merete W. Dees · Roar Moe • \\ Dag-Ragnar Blystad
}

Received: 2 December 2007/Revised: 5 February 2008/Accepted: 20 February 2008/Published online: 8 March 2008

(c) Springer-Verlag 2008

\begin{abstract}
Agrobacterium-mediated transformation for poinsettia (Euphorbia pulcherrima Willd. Ex Klotzsch) is reported here for the first time. Internode stem explants of poinsettia cv. Millenium were transformed by Agrobacterium tumefaciens, strain LBA 4404, harbouring virusderived hairpin (hp) RNA gene constructs to induce RNA silencing-mediated resistance to Poinsettia mosaic virus (PnMV). Prior to transformation, an efficient somatic embryogenesis system was developed for poinsettia cv. Millenium in which about $75 \%$ of the explants produced somatic embryos. In 5 experiments utilizing 868 explants, 18 independent transgenic lines were generated. An average transformation frequency of $2.1 \%$ (range $1.2-3.5 \%$ ) was revealed. Stable integration of transgenes into the poinsettia nuclear genome was confirmed by PCR and Southern blot analysis. Both single- and multiple-copy transgene integration into the poinsettia genome were found among transformants. Transgenic poinsettia plants showing resistance to mechanical inoculation of PnMV
\end{abstract}

Communicated by L. Peña.

J. L. Clarke $(\varangle) \cdot$ C. Spetz · S. Haugslien · S. Xing ·

M. W. Dees - D.-R. Blystad

Plant Health and Plant Protection Division,

Norwegian Institute for Agricultural and Environmental

Research, Hoegskoleveien 7, 1432 Aas, Norway

e-mail: jihong.liu-clarke@bioforsk.no

\section{S. Xing}

Biotechnology Research Center, Jilin Academy of Agricultural

Sciences, No.1363, Caiyu Street, 130124 Changchun, China

M. W. Dees - R. Moe

Department of Plant and Environmental Sciences,

Norwegian University of Life Sciences, P.O. Box 5003,

1432 Aas, Norway were detected by double antibody sandwich enzyme-linked immunosorbent assay (DAS-ELISA). Northern blot analysis of low molecular weight RNA revealed that transgenederived small interfering (si) RNA molecules were detected among the poinsettia transformants prior to inoculation. The Agrobacterium-mediated transformation methodology developed in the current study should facilitate improvement of this ornamental plant with enhanced disease resistance, quality improvement and desirable colour alteration. Because poinsettia is a non-food, non-feed plant and is not propagated through sexual reproduction, this is likely to be more acceptable even in areas where genetically modified crops are currently not cultivated.

Keywords Euphorbia pulcherrima .

Somatic embryogenesis - Transformation .

Agrobacterium tumefaciens . Poinsettia mosaic virus

$\begin{array}{ll}\text { Abbreviations } \\ \text { MS } & \text { Murashige and Skoog (1962) } \\ \text { 2iP } & \text { 2-Isopentenyl adenine } \\ \text { BAP } & \text { 6-Benzylaminopurine } \\ \text { CPA } & \text { 4-Chlorophenoxy acetic acid } \\ \text { IAA } & \text { Indole-3 acetic acid } \\ \text { NAA } & \text { 1-Naphthaleneacetic acid }\end{array}$

Introduction

Poinsettia, Euphorbia pulcherrima Willd. Ex Klotzsch, is a contemporary symbol of Christmas in most parts of the world. Since it was introduced to the United States in 1825 from Mexico, poinsettia has become the primary potted flower produced and sold in North America, Europe, Asia 
and Australia (Ecke et al. 2004; Williams 2005). Today, Europe and North America represent the largest volume of production and sales, but demand is growing quickly in the Australian region as poinsettia becomes more popular each year (Williams 2005). Global production of poinsettia has exceeded hundreds of millions and is still expanding, indicating its economic and market potential for the floral industry.

Genetic engineering is an important tool for breeding ornamental plants with addition of desirable traits such as novel colour, better quality and resistance to pathogens and insects (Mol et al. 1995; Deroles et al. 2002; Hammond 2006; Hammond et al. 2006). This technology has been successfully utilized in the production of a number of important ornamental crops e.g. blue roses (Yoshikazu 2004), novel carnations (http://www.florigene.com), transgenic gladiolus (Kamo et al. 1997) and improvement of chrysanthemums (Teixeira da Silva 2004). To date, transgenic ornamentals of over 30 genera have been produced by different transformation approaches (Hammond 2006; Hammond et al. 2006). However, there are only a few reports describing genetic transformation of poinsettia: one was the US patent 7119262 (Smith et al. 1997) using the biolistic transformation approach, while the other two were electrophoresis-based transformation attempts (Vik et al. 2001; Clarke et al. 2006). Biolistic transformation requires the use of a gene gun device (Sanford et al. 1987) and tends to generate transformants with a high transgene copy number, complex transgene loci and unpredictable silencing of the transgene (Herrera-Estrella et al. 2004). Electrophoresis of DNA into meristems on a living plant was described as a simple method to generate transformants by avoiding tedious tissue culture work and was utilized in producing transgenic orchid (Griesbach 1994). However, no stable transgenic poinsettia was ever produced using electrophoresis, regardless of the strong transient expressions that were detected in both studies (Vik et al. 2001; Clarke et al. 2006). Thus, Agrobacteriummediated transformation for poinsettia was developed in the present study.

Poinsettia mosaic virus (PnMV) is a single-stranded, positive-sense RNA virus (Bradel et al. 2000) that belongs to the family Tymoviridae (Dreher et al. 2005). Infection of poinsettia plants with PnMV results in mosaic symptoms during parts of the growing season (Fulton and Fulton 1980), which in turn decreases the commercial value of this ornamental plant. Thus, growers are interested in the potential benefits of growing PnMV-free poinsettias. PnMV-free poinsettia plants can be obtained by heat treatment or in vitro culture of apical meristems, which are time-consuming and cost-ineffective methods. An additional problem is that PnMV-free poinsettia tends to be rapidly reinfected, although no vector is known (Blystad and Fløistad 2002; Siepen et al. 2005). There is therefore a need for a new and effective alternative approach, like Agrobacterium-mediated transformation, which can overcome these difficulties.

RNA silencing is a mechanism by which transcription or translation of a gene is suppressed. It is known to occur in plants, fungi and animals (Fire et al. 1998; Waterhouse et al. 1998; Baulcombe 2005). It is triggered by double stranded RNA (dsRNA) molecules (Meister and Tuschl 2004), which are subsequently recognized and cleaved by the host-encoded endoribonuclease dicer (Bernstein et al. 2001) into small interfering RNA (siRNA) molecules of 21-26 nucleotides in length (Hamilton and Baulcombe 1999). These siRNAs, in conjunction with the RNAinduced silencing complex (RISC), target RNA molecules with homologous sequences for sequence-specific degradation (Hammond et al. 2000; Bernstein et al. 2001; Tabara et al. 2002). In plants, RNA silencing can be achieved by genetic transformation with gene constructs that express highly transcribed sense, anti-sense or self complementary hairpin RNA (hpRNA) containing sequences homologous to the target gene (Smith et al. 2000; Wesley et al. 2001; Helliwell and Waterhouse 2003). RNA silencing has been efficiently used to generate resistance against plant viruses in many plant species including ornamentals (Metzlaff et al. 1997; Tenllado et al. 2004; Bucher et al. 2006; Hammond et al. 2006).

In this study, we report the development of an A. tumefaciens-mediated transformation method for poinsettia, which has never previously been described for this plant species. This method could facilitate the improvement of poinsettia by introducing new traits into existing commercial poinsettia cultivars in order to meet market demands. Using this approach, in combination with RNA silencing technology, transgenic PnMV resistant poinsettia plants carrying PnMV-derived hpRNA constructs were produced for the first time.

\section{Materials and methods}

\section{Plant materials}

Euphorbia pulcherrima, poinsettia cv. Millenium, plants were kindly supplied by the J. Kristiansen nursery, Grimstad, Norway, in the year 2000. The original stock plants were subjected to heat therapy to eliminate PnMV (Fløistad and Blystad, unpublished). PnMV-free cv. Millenium cuttings were grown in the greenhouse under a photoperiod of $16 \mathrm{~h}$ light and $8 \mathrm{~h}$ dark with a temperature of $22^{\circ} \mathrm{C}$. Internode stem explants from 8 to 10 -week-old cv. Millenium plants were used for somatic embryogenesis and A. tumefaciens-mediated transformation. 
Somatic embryogenesis of poinsettia cv. Millenium

Internode stem explants 5-15 mm long from cv. Millenium plants were excised and used in the establishment of somatic embryogenesis for poinsettia prior to transformation. In Experiments 1 and 2, the explants were surface sterilized for $10 \mathrm{~min}$ in $3 \% \mathrm{NaOCl}$ and then rinsed three times with sterilized deionized and autoclaved $\mathrm{H}_{2} \mathrm{O}$ for 5 , 10 and $15 \mathrm{~min}$ according to Preil (1994). Because of a large number of infections encountered in Experiments 1 and 2, the stem explants were sterilized in Experiment 3 using 70\% ethanol for $1 \mathrm{~min}$ followed by $5 \mathrm{~min}$ with $1 \%$ $\mathrm{NaOCl}$ and 3 rinsings with sterile deionized and autoclaved water for 3, 10 and $20 \mathrm{~min}$, a modification of the protocol of Preil (1994). The modified protocol was repeated twice before being utilized in Experiment 3 and also in subsequent transformation experiments. After sterilization, stem segments of ca. 1-1.5 mm thickness were placed on callus induction (CI) medium [MS medium (Murashige and Skoog 1962) supplemented with $0.2 \mathrm{mg} \mathrm{l}^{-1}$ BAP and $0.2 \mathrm{mg} \mathrm{l}^{-1} \mathrm{CPA}$ and $30 \mathrm{~g} \mathrm{l}^{-1}$ sucrose, Table 1] for 810 days. Embryogenic calli were then transferred to somatic embryo induction (SEI) medium (MS medium contains $0.3 \mathrm{mg} \mathrm{l}^{-1} \mathrm{NAA}$ and $0.15 \mathrm{mg}^{-1} 2 \mathrm{iP}$ and $30 \mathrm{~g} \mathrm{l}^{-1}$ sucrose, Table 1) for somatic embryogenesis. The somatic embryos emerged after an average of 12 weeks were then transferred to somatic embryo maturation (SEM) medium (MS basal medium containing $0.05 \mathrm{mg} \mathrm{l}^{-1}$ BAP and $30 \mathrm{~g}^{-1}$ sucrose, Table 1). Shoots and plantlets derived from somatic embryos were subsequently cultured on root induction (RI) medium consisting of $1 / 2$ strength MS, $2 \mathrm{mg}^{-1}$ IAA and $20 \mathrm{~g} \mathrm{l}^{-1}$ sucrose or on hormone free $1 / 2$ strength MS (HFMS) medium supplemented with $20 \mathrm{~g}^{-1}$ sucrose for root induction (Table 1). Plants with welldeveloped roots were transferred to soil and grown in the greenhouse at $22^{\circ} \mathrm{C}$. The above culture conditions and media compositions for somatic embryogenesis of cv. Millenium were developed according to Preil (1994) with a number of modifications described above. Detailed information regarding media compositions is summarized in Table 1.
Light conditions were $23 \mu \mathrm{E} \mathrm{m}^{-2} \mathrm{~s}^{-1}$ for callus and somatic embryos and $30 \mu \mathrm{E} \mathrm{m}^{-2} \mathrm{~s}^{-1}$ for plantlets in RI and HFMS media with a $16 \mathrm{~h}$ photoperiod. Temperature was constant at $24^{\circ} \mathrm{C}$. A light microscope connected to a digital camera was used to follow the development of the somatic embryos.

Agrobacterium strain and hairpin (hp) RNA constructs

The disarmed A. tumefaciens strain LBA4404 (Hoekema et al. 1983; Invitrogen, California, USA) was utilized throughout the study. Three hpRNA constructs, named as $\mathrm{pCP}, \mathrm{pR} 2$ and $\mathrm{pR} 3$, were generated. Construct $\mathrm{pCP}$ targeted the viral coat protein $(\mathrm{CP})$, whereas constructs $\mathrm{pR} 2$ and pR3 targeted two distinct regions within the viral RNA-dependant RNA-polymerase (RdRp) (Fig. 1a). Briefly, constructs $\mathrm{pCP}, \mathrm{pR} 2$ and $\mathrm{pR} 3$ were generated by amplifying the corresponding fragments from the viral genome and introducing the appropriate restriction sites. The following restriction sites were introduced: $X h o \mathrm{I} \cdot \mathrm{Kp} n \mathrm{I}$ (for sense orientation) and $C l a \mathrm{I} \cdot X b a \mathrm{I}$ (for antisense orientation) for R2 and R3 fragments, and XhoI.EcoRI (sense) and $\mathrm{ClaI} \cdot \mathrm{Xba \textrm {I }}$ (antisense) for $\mathrm{CP}$ fragment. The primers used are presented in Table 2. Each amplified fragment was $500 \mathrm{bp}$ long. Subsequently, the fragments were inserted into pHANNIBAL vector (kindly provided by CSIRO Plant Industry, Canberra, Australia) in sense and antisense orientations, interrupted by an intron pyruvate orthophosphate dikinase ( $p d k)$ gene (Fig. 1b) as described by Helliwell and Waterhouse (2003). The three expression cassettes were cloned into pART27 (Gleave 1992, kindly provided by CSIRO Plant Industry, Canberra, Australia), a binary plasmid vector, at Not 1 site under the control of CaMV $35 \mathrm{~S}$ promoter and with ocs terminator (Helliwell and Waterhouse 2003), generating hpRNA constructs pCP, pR2 and pR3 (Fig. 1b). For selection, the neomycin phosphotransferase II (nptII) gene conferring kanamycin resistance was used under the control of nopaline synthase promoter (Nos-P) and with Nos terminator (NosT, Fig. 1b) in the binary plasmid expression vector pART27. Sequence analysis was utilized to verify the junctions and orientations in the

Table 1 Media names and compositions modified according to Preil (1994)

\begin{tabular}{|c|c|c|c|c|c|c|c|}
\hline Medium & MS & Sucrose $(\%)$ & $\mathrm{CPA}\left(\mathrm{mg} \mathrm{l}^{-1}\right)$ & $\mathrm{BAP}\left(\mathrm{mg} \mathrm{l}^{-1}\right)$ & NAA $\left(\mathrm{mg}^{-1}\right)$ & $2 \mathrm{iP}\left(\mathrm{mg} \mathrm{l}^{-1}\right)$ & IAA $\left(\mathrm{mg} \mathrm{l}^{-1}\right)$ \\
\hline CI & Full strength & 3 & 0.2 & 0.2 & - & - & - \\
\hline SEI & Full strength & 3 & - & - & 0.3 & 0.15 & - \\
\hline SEM & Full strength & 3 & - & 0.05 & - & - & - \\
\hline RI & $1 / 2$ strength & 2 & - & - & - & - & 2 \\
\hline HFMS & $1 / 2$ strength & 2 & - & - & - & - & - \\
\hline
\end{tabular}

$C I$ Callus induction medium, SEI somatic embryo induction medium, SEM somatic embryo maturation medium, $R I$ root induction medium, HFMS hormone free MS medium for root induction 
Fig. 1 Schematic representation of PnMV genome (a) and hairpin (hp) RNA constructs used in the current study (b). The locations of the primers used to generate the constructs as well as for screening purposes are presented over the PnMV genome. Sequences of the primers are presented in Table 2. The location of the probe used to detect siRNA is presented below the PnMV genome (see "Materials and methods"). $C P$ coat protein region, $R 2$ and $R 3$ RNAdependent RNA-polymerase (RdRp) regions of the PnMV genome

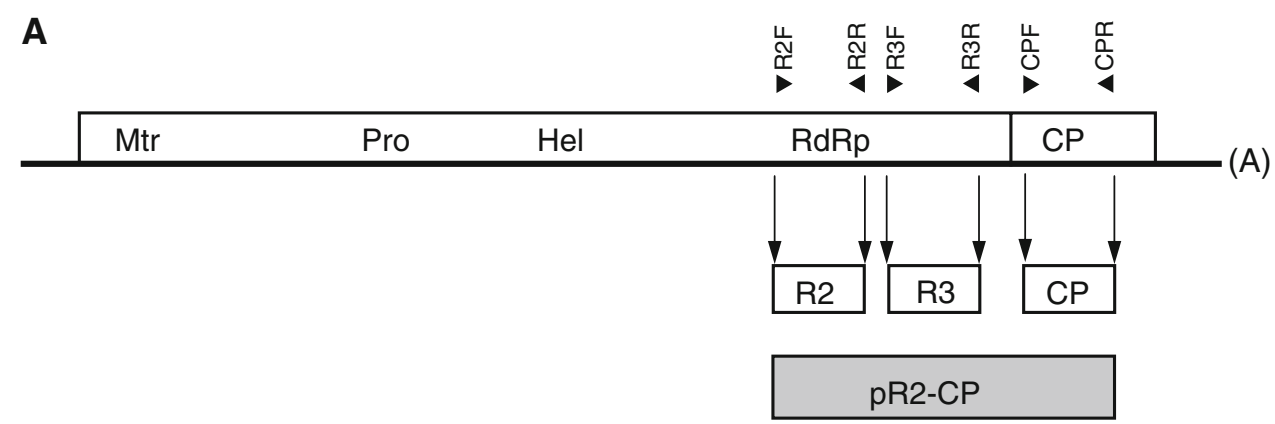

B
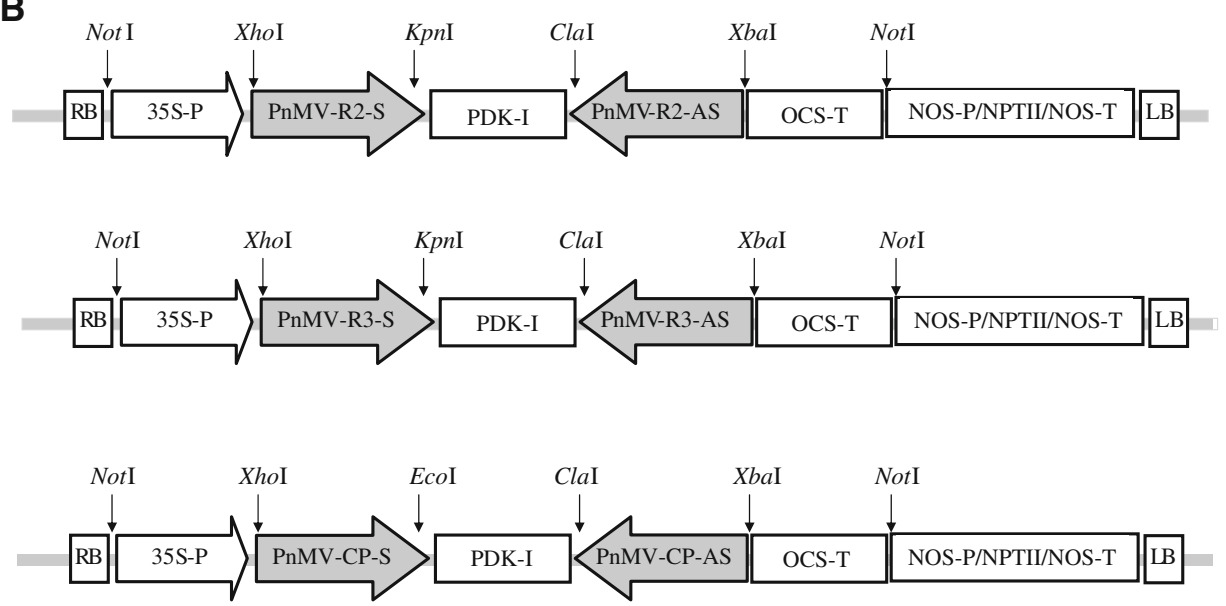

expression vectors $\mathrm{pCP}, \mathrm{pR} 2$ and $\mathrm{pR} 3$. All three plasmid vectors were introduced into A. tumefaciens strain LBA 4404 by electroporation according to the manufacturer's instructions (Invitrogen, California, USA).

Transformation of poinsettia stem explants

A. tumefaciens strain LBA4404, harbouring the plasmid pCP, pR2 or pR3, was grown overnight in $15 \mathrm{ml}$ liquid LB medium supplemented with $50 \mathrm{mg}^{-1}$ kanamycin (SigmaAldrich, St Louis, USA) at $28^{\circ} \mathrm{C}$ with shaking at $200 \mathrm{rpm}$ until an $\mathrm{OD}_{600}$ of 0.6-0.8 was reached. The bacterium suspension was collected at 2,700 rpm for $10 \mathrm{~min}$, washed twice with MS basal medium supplemented with $2 \%$ sucrose (MS-2), and resuspended in $10 \mathrm{ml}$ MS-2.

The internode stem explants taken from 8 to 10 -weekold poinsettia plants derived from cuttings were disinfected as described above, excised into stem segments with 1$1.5 \mathrm{~mm}$ thickness and inoculated with Agrobacterium suspension for $5 \mathrm{~min}$ with gentle shaking. After the infection, stem segments were blotted briefly with sterile filter paper and placed on CI medium at $24^{\circ} \mathrm{C}$ in the dark for $72 \mathrm{~h}$ without selection. After co-cultivation, the explants were blotted gently on sterile filter paper and transferred to the CI medium with selection and light conditions as described above.

Table 2 Primers used in this study

\begin{tabular}{|c|c|c|c|}
\hline Primer name & Restriction sites & Sequence $^{\mathrm{a}}$ & Location \\
\hline $\mathrm{R} 2 \mathrm{~F}-\mathrm{XhK}$ & XhoI, KpnI & ctcgagggtaccTTTAGCAAAACGCAGCACAAAATCA & $4,371-4,395$ \\
\hline $\mathrm{R} 2 \mathrm{R}-\mathrm{CXb}$ & ClaI, XbaI & catcgattctagaTCTCCAGACACCATGATTGGGTG & $4,848-4,870$ \\
\hline R3F-XhK & XhoI, KpnI & ctcgagcggtaccTTCGCTTTAAAACAGAAAGCACCA & $4,939-4,962$ \\
\hline $\mathrm{R} 3 \mathrm{R}-\mathrm{CXb}$ & ClaI, XbaI & catcgatgtctagaGCCTCGTAGCTTGGTTGGGTT & $5,418-5,438$ \\
\hline $\mathrm{CPF}-\mathrm{XhE}$ & XhoI, EcoRI & ctcgaggaattcAACCACGTCGACTCCACTCCAT & $5,478-5,499$ \\
\hline $\mathrm{CPR}-\mathrm{CXb}$ & ClaI, XbaI & atcgattctagaAGCTTGCCGCTCACCAGCAC & $5,958-5,977$ \\
\hline
\end{tabular}

${ }^{a}$ Primer sequences are presented in the $5^{\prime}-3^{\prime}$ orientation. Sequences complementary to the viral genome are presented in uppercase letters whereas non-complementary restriction sites included in each primer are presented in lowercase letters. The primers used for screening purposes are identical to the ones presented but do not include the non-complementary restriction sites 
Selection and regeneration of transgenic plants

After 8-10 days on CI medium supplemented with $500 \mathrm{mg} \mathrm{l}^{-1}$ claforan (Aventis Pharma Ltd, Norway) and $10 \mathrm{mg} \mathrm{l}^{-1}$ kanamycin, the explants were transferred to SEI medium supplemented with $400 \mathrm{mg} \mathrm{l}^{-1}$ claforan and $25 \mathrm{mg} \mathrm{l}^{-1}$ kanamycin for somatic embryogenesis. The protocol for somatic embryogenesis is detailed above. The somatic embryos obtained after about 12 weeks were then transferred to the SEM medium supplemented with $400 \mathrm{mg}^{-1}$ claforan and $10 \mathrm{mg} \mathrm{l}^{-1}$ kanamycin. Shoots and plantlets derived from somatic embryos were subsequently cultured on RI medium or on hormone free $1 / 2$ strength MS (HFMS) medium (Table 1) for root induction and were subsequently transferred to soil and grown in the greenhouse at $22^{\circ} \mathrm{C}$.

Screening of transgenic poinsettia plants

Screening of transgenic poinsettia plants was carried out by PCR. The primer pairs used to amplify the CP, R2 and R3 fragments were the same as those for vector constructions, but did not include any additional restriction site (Table 2). HotStarTaq PCR kit purchased from Qiagen (Valencia, California) was used in PCR screening of transformants. Twenty micro litres of reaction mixture containing $2 \times$ HotStarTaq Mastermix, $0.4 \mu \mathrm{M}$ of each primer, $0.1 \mu \mathrm{g}$ template DNA and $\mathrm{H}_{2} \mathrm{O}$ were subjected to PCR amplification under the following conditions: $15 \mathrm{~min}$ at $95^{\circ} \mathrm{C}(1$ cycle), $30 \mathrm{~s}$ at $95^{\circ} \mathrm{C}, 30 \mathrm{~s}$ at $55^{\circ} \mathrm{C}, 1 \mathrm{~min}$ at $72^{\circ} \mathrm{C}(35$ cycles) and a final extension $10 \mathrm{~min}$ at $72^{\circ} \mathrm{C}(1$ cycle $)$ according to the manufacturer's instructions. All the PCR amplification was performed using Applied Biosystems 96 Thermal Cycler (Applied Biosystems). PCR products were analysed by electrophoresis on $0.8 \%(\mathrm{~W} / \mathrm{V})$ agarose gels.

\section{Southern blot analysis}

To confirm the stable integration of transgenes into the poinsettia genome and to evaluate transgene copy number, Southern blot analysis was performed, basically as described by Sambrook et al. (1989). Total genomic DNA was isolated from young leaves of control plant and the putative transformants using a modified CTAB protocol as described by Rogers and Bendich (1988). Ten micrograms of genomic DNA was digested with the restriction enzyme HindIII for $4 \mathrm{~h}$ and separated on a $1 \%(\mathrm{~W} / \mathrm{V})$ TBE agarose gel overnight at $37 \mathrm{~V}$ followed by transfer onto Gene Screen Transfer membrane (NEN ${ }^{\mathrm{TM}}$ Life Science Products Inc., Boston, MA, USA). The HindIII site is not present in the $\mathrm{pCP}, \mathrm{pR} 2$ and $\mathrm{pR} 3$ vectors. The HindIII site from the pHANNIBAL vector was removed during the vector construction. Membranes were hybridized overnight with
${ }^{32} \mathrm{P}$-labelled probe of $1.5 \mathrm{~kb}$ in size targeting the $\mathrm{CP}, \mathrm{R} 2$ and R3 regions (Fig. 1a). The probe was generated by amplifying a $1.5 \mathrm{~kb}$ fragment that included the R2, R3 and $\mathrm{CP}$ regions used to generate the hairpin RNA constructs $\mathrm{pR} 2, \mathrm{pR} 3$ and $\mathrm{pCP}$. This allowed us to use one probe instead of three probes for southern blot analyses of $\mathrm{pR} 2$, $\mathrm{pR} 3$ and $\mathrm{pCP}$ transformants.

Northern blot hybridization of low molecular weight RNA

Total RNA was extracted using the Trizol reagent (Invitrogen, USA) as recommended by the manufacturer. Low molecular weight (LMW) RNA was separated from high molecular weight RNA by precipitation with 1 volume of $4 \mathrm{M} \mathrm{LiCl}_{4}$ at $4^{\circ} \mathrm{C}$ overnight. After centrifugation, the LMW RNA-containing supernatant was transferred to a new tube and precipitated with 1 volume of isopropanol. LMW RNA concentrations were measured using a GeneQuant II spectrophotometer (Amersham Biosciences, UK) and RNA quality was verified by agarose gel electrophoresis. LMW RNA (approximately $30 \mu \mathrm{g}$ ) was mixed with 1 volume of Tris-borate-EDTA-urea sample buffer (Bio$\mathrm{rad}$, USA) and heated at $100^{\circ} \mathrm{C}$ for $5 \mathrm{~min}$. Subsequently, LMW RNA was separated on a $15 \%$ polyacrylamid trisborate-EDTA-urea gel and transferred to a Hybond-N membrane (Amersham Biosciences, UK) overnight. The membranes were hybridized with a digoxigenin (DIG)labelled (Roche Diagnostics, Germany) RNA probe (Fig. 1a), previously cleaved by alkaline hydrolysis to generated fragments of approximately $50 \mathrm{bp}$ as described by Hamilton and Baulcombe (1999). After hybridization the membranes were washed at room temperature, $2 \times 15$ $\min$ in $5 \times \mathrm{SSC}+0.5 \%$ SDS and $2 \times 15 \mathrm{~min} 1 \times$ SSC $+0.5 \%$ SDS and then exposed to films.

Virus inoculation and detection

Sap from poinsettia and $N$. benthamiana plants systemically infected with PnMV was used as an inoculum. Approximately $0.5 \mathrm{~g}$ of infected leaf tissue was ground with $4 \mathrm{ml}$ of inoculation buffer [0.03 M sodium phosphate buffer ( $\mathrm{pH}$ 8)] and mechanically inoculated to leaves of three to fourleaves stage plants lightly dusted with carborundum. Plants were grown in the greenhouse at $22-24^{\circ} \mathrm{C}$.

Detection of PnMV infection by double antibody sandwich enzyme-linked immunosorbent assay (DAS-ELISA) was carried out at 6 and 10 weeks post-inoculation basically as described by Clark and Adams (1977). The uppermost fully expanded leaves of each plant were collected in polyvinyl bags (Bioreba, USA). Extraction buffer [100 mM phosphate buffer (pH 7.4), $20 \mathrm{mM}$ Tris, $137 \mathrm{mM}$ $\mathrm{NaCl}, 3 \mathrm{mM} \mathrm{KCl}, 2 \%$ PVP $24 \mathrm{kD}, 0.05 \%$ Tween 20, and 
$0.02 \% \mathrm{NaN}_{3}$ ] was added to the bags $(1 / 10 \mathrm{w} / \mathrm{v})$ and the samples were macerated. A measure of $100 \mu \mathrm{l}$ of the homogenates were transferred to wells of microtitre plates previously coated with $100 \mu \mathrm{l}$ of PnMV IgG (Agdia, USA) diluted $1 / 1,000$ in coating buffer [50 $\mathrm{mM}$ carbonatebicarbonate buffer ( $\mathrm{pH} 9.6$ ) and $0.02 \% \mathrm{NaN}_{3}$ ], followed by incubation at $+4^{\circ} \mathrm{C}$ overnight. Microtitre plates were washed with washing buffer $[10 \mathrm{mM}$ phosphate buffer $(\mathrm{pH}$ 7.4), $140 \mathrm{mM} \mathrm{NaCl}, 3 \mathrm{mM} \mathrm{KCl}$, and $0.05 \%$ Tween 20] and $100 \mu \mathrm{l}$ of alkaline phosphatase conjugated PnMV IgG (Agdia, USA) diluted $1 / 1,000$ in extraction buffer was added to each well. Microtitre plates were incubated at $+4^{\circ} \mathrm{C}$ overnight. Subsequently, they were washed with washing buffer and $100 \mu \mathrm{l}$ of substrate buffer [1 M diethanolamine ( $\mathrm{pH}$ 9.8) and $\left.0.02 \% \quad \mathrm{NaN}_{3}\right]$ containing $p$ nitrophenyl phosphate $\left(0.5 \mathrm{mg} \mathrm{m}^{-1}\right)$ was added.
Absorbance values were recorded at $405 \mathrm{~nm}$ with an Expert plus microtitre plate reader using the Kim software (ASYS HITECH, Austria). Values were considered positive when the $A_{450}$ value was twofold higher than that of the negative control.

\section{Results}

Establishment of somatic embryogenesis for poinsettia cv. Millenium

An efficient protocol for somatic embryogenesis of poinsettia cv. Millenium was developed. Stem explants of cv. Millenium responded well to the induction media and a large number of somatic embryos were effectively induced

Table 3 Experiments and efficiency of somatic embryogenesis

\begin{tabular}{lllllr}
\hline Experiment & $\begin{array}{l}\text { No. of } \\
\text { explants }\end{array}$ & $\begin{array}{l}\text { \% of embryogenic } \\
\text { explants }\end{array}$ & $\begin{array}{l}\text { Range of SE/embryogenic } \\
\text { explant }\end{array}$ & $\begin{array}{l}\text { Mean } \\
\text { SE/embryogenic } \\
\text { explant }^{\mathrm{a}}\end{array}$ \\
\hline 1 & 200 & 21 & $2-10$ & $\begin{array}{l}\text { No. of } \\
\text { regenerated } \\
\text { plantlets }^{\mathrm{b}}\end{array}$ \\
2 & 200 & 37 & $2-14$ & $5.3 \pm 2.4$ & 70 \\
3 & 350 & 75 & $3-18$ & $7.8 \pm 3.1$ & 7.1 \\
\hline
\end{tabular}

$S E$ somatic embryos

${ }^{\text {a }}$ Values are presented with their corresponding standard deviation

${ }^{\mathrm{b}}$ Regenerated plantlets after 14 weeks

Fig. 2 Somatic embryogenesis in poinsettia cv. Millenium: a embryogenic structure and globular stage somatic embryos (arrows) that appeared on the callus (bar $1 \mathrm{~mm})$, b cotyledonary stage of somatic embryos (bar $1 \mathrm{~mm}$ ), c plantlets deriving from somatic embryos on RIM medium; and d regenerated plants established in the greenhouse
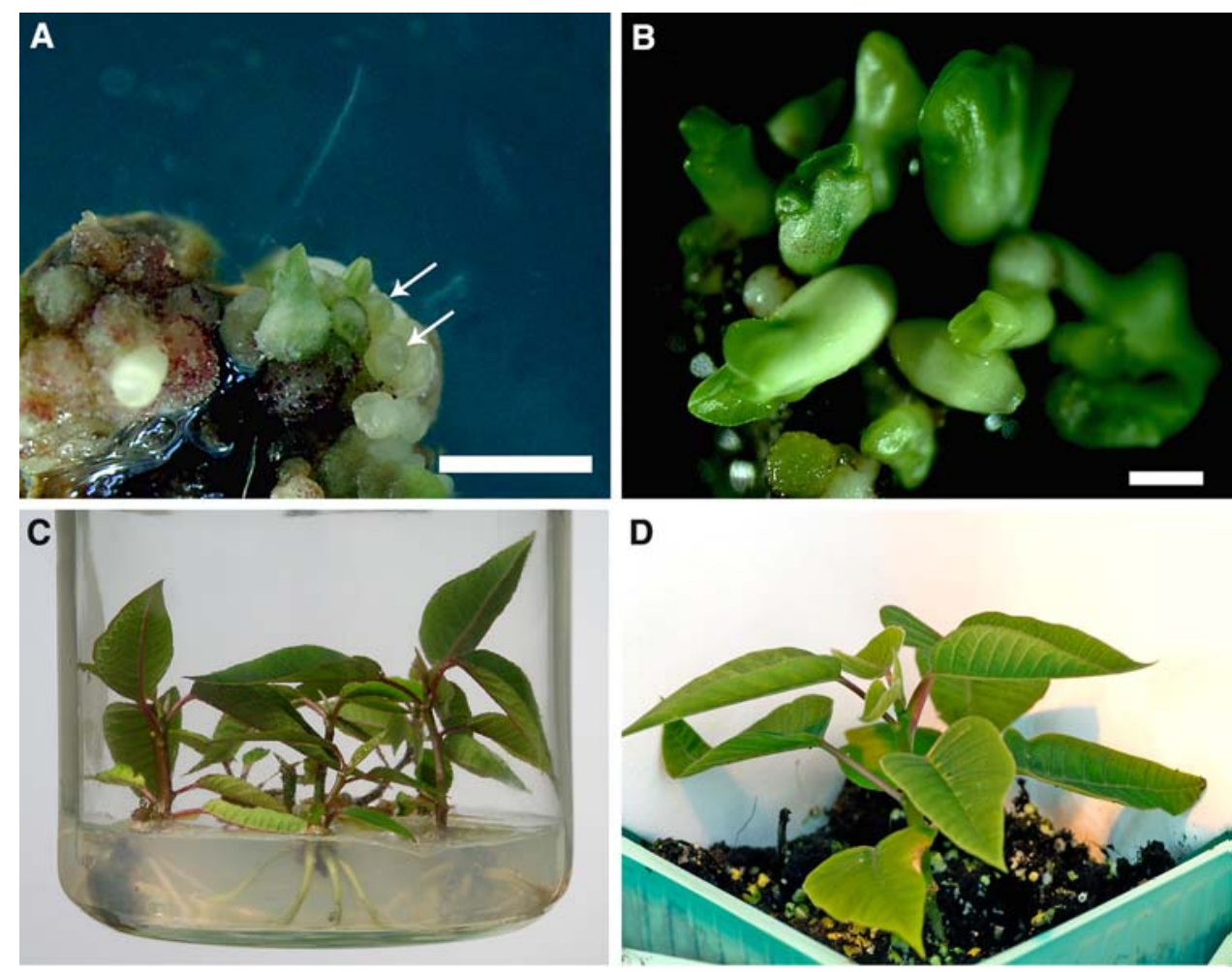

D

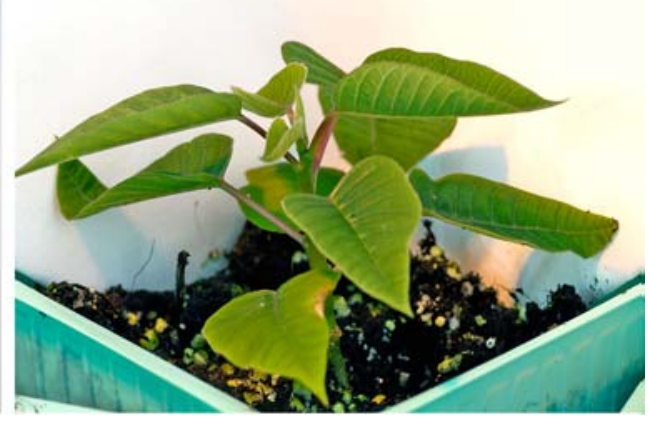


(Table 3; Fig. 2a-d). In Experiments 1 and 2, somatic embryos could only be induced from 21 to $37 \%$ of the explants due to infection, whereas more than $75 \%$ of the explants produced somatic embryos in Experiment 3 after the modification of the disinfection protocol. The average numbers of somatic embryos on each embryogenic callus varied from $5.3 \pm 2.4$ and $5.8 \pm 3.1$ for Experiments 1 and 2, respectively, to $7.2 \pm 4.1$ for Experiment 3 (Table 3). The highest induction of somatic embryos was found in Experiment 3 with 18 somatic embryos on a single callus. When globular stage somatic embryos (Fig. 2a, arrowed) reached the mature stage (Fig. 2b), they became loosely attached to the calli. Shoots derived from somatic embryos were subsequently cultured on RI medium or HFMS medium (Fig. 2c) for root induction and were transferred into the greenhouse when the roots were well established (Fig. 2d). The three experiments conducted and the efficiency of somatic embryogenesis are summarized in Table 3.

The RI and HFMS media used for root induction did not show any clear differences in the percentage (85 and $87 \%$ for RI and HFMS, respectively) of plants that developed roots 3 weeks after being transferred to the rooting media.

Development of the A.tumefaciens-mediated transformation method

Prior to the production of transgenic poinsettia plants, a number of optimizations were carried out to reveal the most suitable conditions for inoculation and co-cultivation, concentration of antibiotic for eliminating A. tumefaciens after co-cultivation, and kanamycin selection without inhibiting somatic embryogenesis and regeneration of plants. Results showed that the optimal inoculation time was 5 min with gentle shaking, while the most suitable cocultivation time was $72 \mathrm{~h}$ (Table 4). Using this combination, 26 out of the 80 (33\%) explants tested PCR positive after inoculation, co-cultivation and 2 weeks on claforan (Table 4). Those explants were followed and showed normal embryogenesis and regeneration as compared to the control (data not shown). Therefore, these conditions were utilized throughout all the transformation experiments. When inoculation time exceeded $20 \mathrm{~min}$ followed by a co-cultivation period of 6 days, only $4 \%$ of the explants

Table 4 Number of PCR positive explants that survived 2 weeks after Agrobacterium inoculation and co-cultivation treatments. A total of 80 explants were used in each treatment

\begin{tabular}{lrrc}
\hline Co-cultivation time (days) & \multicolumn{4}{l}{ Inoculation time } \\
\cline { 2 - 4 } & $5 \mathrm{~min}$ & $10 \mathrm{~min}$ & $20 \mathrm{~min}$ \\
\hline 2 & $9(11 \%)$ & $13(16 \%)$ & $21(26 \%)$ \\
3 & $26(33 \%)$ & $21(26 \%)$ & $20(25 \%)$ \\
6 & $10(13 \%)$ & $8(10 \%)$ & $3(4 \%)$ \\
\hline
\end{tabular}

survived due to the overgrowth of Agrobacterium on the surfaces of the explants (Table 4).

For elimination of Agrobacterium growth after co-cultivation, the optimized concentration of claforan was $500 \mathrm{mg} \mathrm{l}^{-1}$ for the CI medium, whereas $400 \mathrm{mg} \mathrm{l}^{-1}$ claforan was an adequate concentration for the SEI and SEM media. For selection of transformed cells, $25 \mathrm{mg} \mathrm{l}^{-1}$ kanamycin was found optimal for the SEI medium, while $10 \mathrm{mg}^{-1}$ kanamycin was optimal for the CI and SEM media.

Production of transgenic poinsettia plants, molecular analyses and resistance assays

To produce transgenic poinsettia plants, 5 transformation experiments including 868 stem segment explants were carried out using the established inoculation, co-cultivation and selection conditions described above. Of those explants, 228 (26.3\%) somatic embryo-derived plants were obtained. The results are summarised in Table 5.

PCR analysis was conducted for screening the putative transformants. All 228 regenerated plants were analysed by PCR and 18 transformants were revealed. Of these, three possessed $\mathrm{pCP}$ constructs, while six and nine contained pR2 and pR3 constructs, respectively (Fig. 3a-c). Transformation frequency varied from 1.2 to $3.5 \%$ with an average transformation frequency of $2.1 \%$ (Table 5).

Southern blot analysis was performed on selected PCR positive plants with satisfactory characteristics for studying transgene integration and estimating the transgene copy number. Results of Southern blot analysis confirmed the stable integration of transgene and both single- and multiple-copy transgene integration into the poinsettia genome were detected among the transformants (Fig. 4). Of the eight transformants analysed, six showed single copy integration of transgene (lanes 2-6 and 9 in Fig. 4) with fragment size greater than the length of intact T-DNA

Table 5 Summary of five Agrobacterium-mediated transformation experiments on poinsettia cv. Millenium with pCP, pR2 and pR3 constructs

\begin{tabular}{lllll}
\hline Experiment $^{\mathrm{a}}$ & $\begin{array}{l}\text { No. of } \\
\text { explants }\end{array}$ & $\begin{array}{l}\text { No. of } \\
\text { regenerated } \\
\text { plants }\end{array}$ & $\begin{array}{l}\text { No. of } \\
\text { transformants }\end{array}$ & $\begin{array}{l}\text { Transformation } \\
\text { efficiency (\%) }\end{array}$ \\
\hline $1(\mathrm{CP})$ & 185 & 54 & 3 & 1.6 \\
$2(\mathrm{R} 3)$ & 132 & 69 & 3 & 2.3 \\
$3(\mathrm{R} 3)$ & 172 & 66 & 6 & 3.5 \\
$4(\mathrm{R} 2)$ & 254 & 21 & 3 & 1.2 \\
$5(\mathrm{R} 2)$ & 125 & 18 & 3 & 2.4 \\
\hline
\end{tabular}

${ }^{\mathrm{a}} \mathrm{CP}, \mathrm{R} 3$, and R2 represent transformation experiments with constructs $\mathrm{pCP}, \mathrm{pR} 2$ and $\mathrm{pR} 3$, respectively

b Transformants verified by PCR and Southern blot analysis

c Number of transformants/total number of explants transformed 

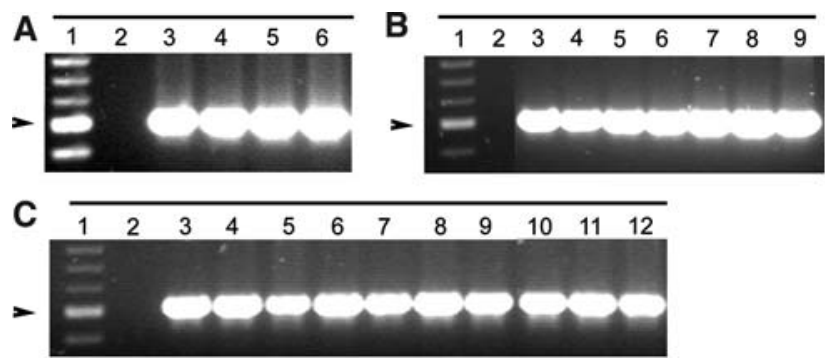

Fig. 3 PCR analysis. PCR positive transformants detected with primer pairs for (a) $\mathrm{CP}$, (b) R2 and (c) R3 fragments respectively. Lane A1 $1 \mathrm{~kb}$ marker; lane A2 non-transformed plant; lanes A3-5 are independent CP-transgenic lines 11-1, 11-2 and 3-1; lane A6 plasmid control. Lane B1 $1 \mathrm{~kb}$ marker; lane B2 non-transformed plant; lanes $B 3-8$ are R2-transgenic lines 72-1, 72-2, 75-2, 79-1, 84-2, and 84-4; lane $B 9$ plasmid control. Lane $C 11 \mathrm{~kb}$ marker; lane $C 2$ nontransformed plant, lanes $C 3-11$ are R3 transgenic lines 18-1, 30A, 381, 40A, 40B, 41-2, 41-5, 56-2 and 62-1; lane C12, plasmid control. The $500 \mathrm{bp}$ band of the $100 \mathrm{bp}$ marker is depicted with an arrow

(ca $7.5 \mathrm{~kb}$ ). However, two pR3 transformants (lanes 7-8 in Fig. 4) showed multiple-copy transgene integration with both large (intact T-DNA) and small fragments (partial, non intact T-DNA).

Furthermore, Northern blot analysis of low molecular weight RNA was carried out on the transgenic plants harbouring constructs $\mathrm{pCP}, \mathrm{pR} 2$ and $\mathrm{pR} 3$, prior to inoculation. Transgene-derived siRNA molecules of 21-26 nucleotides length were detected in transgenic lines pCP 11-1, pCP 3-1, pR2 72-1, pR2 72-2 and pR3 18-1 (Fig. 5). This data indicated that the transgene had been transcribed and converted into siRNAs (Fig. 5). Due to limitations in the

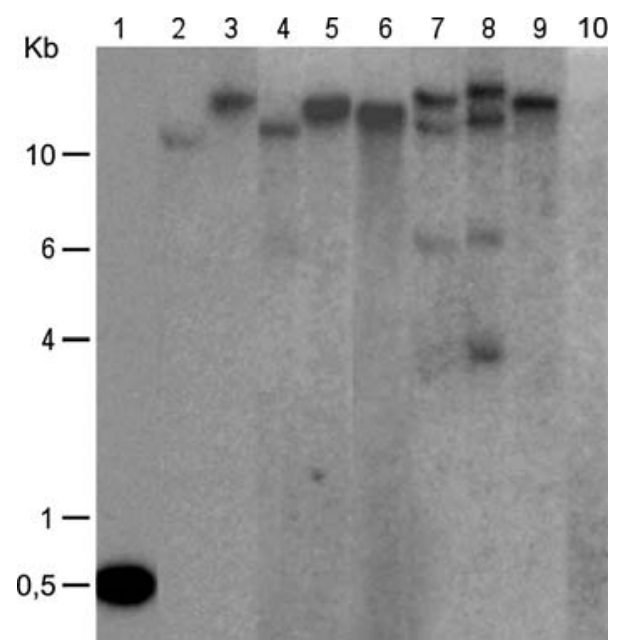

Fig. 4 Southern blot analysis of selected PCR positive transformants carrying $\mathrm{pCP}, \mathrm{pR} 2$ and $\mathrm{pR} 3$ constructs. The HindIII-digested total genomic DNA was probed with a $1.5 \mathrm{~kb}$ probe homologous to the region of CP, R2 and R3 fragments (Fig. 1) allowing us to analyse all the three different types of transformants $(\mathrm{CP}, \mathrm{R} 2$ and $\mathrm{R} 3$ transformants) at the same time. Lane 1 plasmid control; lanes 2-4 CP transformants 11-1, 11-2 and 3-1; lanes 5-6 R2 transformants 72-2, 79-1; lanes 7-9 R3 transformants 38-1, 40B, 18-1; lane 10 negative control

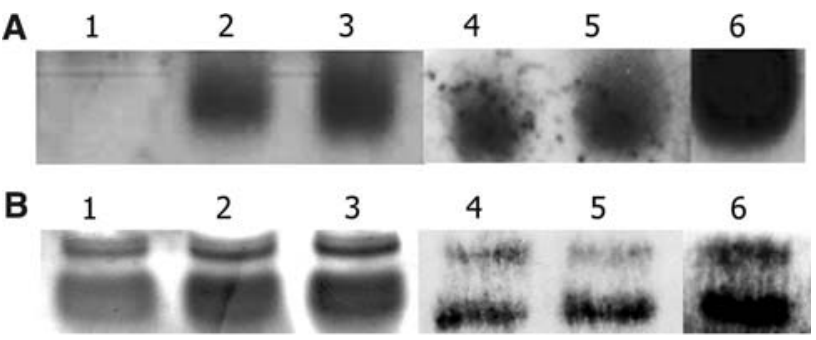

Fig. 5 Northern blot analysis of low molecular weight (LMW) RNA to detect small interfering RNAs (siRNA) in non-inoculated transgenic plants and non-inoculated control. a Lane 1 control; lanes 2-3 CP transgenic lines 11-1, 3-1; lanes 4-5 R2 transgenic lines 72-1,722; lane 6 R3 transformant, 18-1. Ribosomal RNA is presented in (b) to indicate presence of LMW RNA in the gel. Lane 1 control; lanes 2 and 3 PCP transformed plants; lanes 4 and 5 PR2 transformed plants; lane 6 PR3 transformed plant

amount of LMW RNA from transgenic pR3 lines 40B, 41-2, 62-1 and 41-5, these lines were not included in the experiment.

Transgenic plants and non-transformed controls were mechanically inoculated with PnMV at a three to four leaves stage. The upper non-inoculated leaves were tested by DAS-ELISA at 6 and 10 weeks post-inoculation. Results showed that the control plants were systemically infected with PnMV, whereas the tested transgenic lines carrying $\mathrm{pCP}$ and $\mathrm{pR} 2$ constructs remained virus free (Table 6). However, of the five pR3-containing transgenic

Table 6 Immunological detection of PnMV on non-transformed and transformed poinsettia plants inoculated with PnMV

\begin{tabular}{llll}
\hline Construct & Transgenic plant $^{\mathrm{a}}$ & \multicolumn{2}{l}{ ELISA $^{\mathrm{b}}$} \\
\cline { 3 - 4 } & & $6 \mathrm{wpi}$ & $10 \mathrm{wpi}$ \\
\hline $\mathrm{R} 2$ & $72-1$ & 0.1 & 0.1 \\
$\mathrm{R} 3$ & $72-2$ & 0.1 & 0.2 \\
& $18-1$ & 0.1 & 0.2 \\
& $40 \mathrm{~B}$ & 0.8 & 2.4 \\
& $41-2$ & 0.5 & 2.6 \\
& $62-1$ & 0.1 & 0.2 \\
$\mathrm{CP}$ & $41-5$ & 0.7 & 2.8 \\
& $11-1$ & 0.1 & 0.2 \\
Control + & $3-1$ & 0.1 & 0.1 \\
& 1 & 0.8 & 2.8 \\
Control - & 2 & 0.8 & 2.7 \\
& 1 & 0.1 & 0.2 \\
& 2 & 0.2 & 0.2 \\
& 3 & 0.2 & 0.2 \\
& 4 & 0.1 & 0.1 \\
\hline
\end{tabular}

wpi Weeks post inoculation

a One plant per transgenic line was challenged in this assay

b ELISA absorbance values (405 nm) after $60 \mathrm{~min}$ of incubation at room temperature are presented. Samples with twice the value of the highest negative control sample were deemed positive 
lines studied, two lines remained virus free, while the remaining three lines were systemically infected (Table 6).

\section{Discussion}

Significance of genetic engineering in control of virus diseases in ornamentals

The application of genetic engineering in the floriculture industry has clearly become instrumental and rewarding in meeting the demand for novel desirable traits. A number of genetic engineering approaches have been developed for ornamental plants (Griesbach 1994; Kamo et al. 1995; Deroles et al. 1997; Zuker et al. 1998; Kamo et al. 2000; Kishimoto et al. 2002; Kim et al. 2004; Teixeira da Silva 2004; Hammond 2006 and the current study) to facilitate the improvement of ornamental crops with better quality and enhanced resistance against diseases and pests. Effective resistance against viruses conferred by transgenes has shown significant potential because no chemical can be applied for control of virus diseases. Regardless of the importance, only a few reports have been published demonstrating the virus resistance obtained in ornamentals through genetic engineering (Kamo et al. 1997; review by Hammond et al. 2006). Furthermore, many of the ornamentals were transformed only with marker genes like gus or selectable antibiotic or herbicide resistant markers (Deroles et al. 2002). Using the Agrobacterium-mediated transformation protocol developed in the current study, we have obtained PnMV resistant transgenic poinsettia lines expressing viral sequences targeting the $\mathrm{CP}$ and $\mathrm{RdRp}$ regions of the PnMV genome. To our knowledge, no PnMV resistance has previously been obtained using classical or molecular breeding approaches, demonstrating the potential of the transgenic lines produced in the present study for the poinsettia industry.

Somatic embryogenesis and Agrobacterium-mediated transformation in poinsettia $\mathrm{cv}$. Millenium

One of the reasons that transformation of ornamental plants has lagged somewhat behind that of major crops is the lack of efficient regeneration systems, as these are key components leading to the successful development of transformation protocols. Moreover, both transformation and regeneration can be cultivar- or even genotypedependent. Therefore, we developed an efficient somatic embryogenesis system for poinsettia cv. Millenium prior to transformation, although a number of somatic embryogenesis systems were reported previously for old cultivars such as Angelika, Franzi and Diamond (Preil and Beck 1991; Preil 1994; Osternack et al. 1999). A recent study on somatic embryogenesis of cv. Freedom Red and Freedom White demonstrated the influence of cultivar and even plant genotype on somatic embryogenesis in poinsettia (Castellanos et al. 2006), indicating the necessity of developing an effective regeneration system for the individual cultivar prior to the development of transformation systems.

Poinsettia, like other Euphorbia species, produces latex, a milky solution exuded from cut surfaces. When explants were excised from greenhouse grown poinsettia plants, the latex was released from the cutting points, making surface sterilization difficult. In Experiments 1 and 2, a very low percentage of explants produced somatic embryos due to a severe infection found in the callus induction culture (Table 3). This is likely to have been the result of a combination of latex and insufficient sterilization based on the sterilization procedure described for cv. Angelika, Franzi and Diamond (Preil 1994), which might not be optimal for cv. Millenium (Table 3). A modified protocol was thus used for surface sterilization in Experiment 3 as well as in the five transformation experiments, and the efficiency of somatic embryogenesis was greatly improved (see Table 3), demonstrating the significance of optimization of sterilization and regeneration protocols for the individual cultivar.

In addition to the availability of an efficient regeneration system, successful A. tumefaciens-mediated transformation depends on several factors, e.g. inoculation and co-cultivation times with $A$. tumefaciens, antibiotic selection and regeneration. The optimized infection conditions and cocultivation times in our study (Table 4) are consistent with the range of published reports on ornamental plants, where 5-30 min infection time and 1-6 days co-cultivation have been reported (Aida et al. 1999; Kishimoto et al. 2002; Cui and Ezura 2003; Kim et al. 2004; Teixeira da Silva 2004). However, in our study, 6 days co-cultivation led to $A$. tumefaciens overgrowth and explant death, thus differing from the results for Begonia, in which 6 days co-cultivation is required (Kishimoto et al. 2002). These data indicate that co-cultivation times vary among different plant species.

Antibiotic selection is another key factor influencing the establishment of a transformation protocol. To eliminate Agrobacterium after co-cultivation, several antibiotics such as cefotaxim (claforan), carbenecillin, and timentin have been used in previous studies. The influence of the type of antibiotic and/or concentration on each transformation system varies greatly (Ishida et al. 1996; Nauerbey et al. 1997; Sunikumar and Rathore 2001). In the present study, optimised concentrations of claforan in the CI, SEI and SEM media effectively eliminated Agrobacterium. For selecting transformed cells, the nptII gene was used. Although selection media containing 50 and $100 \mathrm{mg} \mathrm{l}^{-1}$ 
kanamycin have been documented in the production of transgenic plants (Kishimoto et al. 2002; Kim et al. 2004; Wu et al. 2005), those concentrations severely inhibited the development of embryogenic calli and somatic embryos in poinsettia. In our study the optimal concentrations of kanamycin were 10 and $25 \mathrm{mg} \mathrm{l}^{-1}$. In the case of Agrobacterium-mediated transformation of Platanus acerifolia, kanamycin at $20 \mathrm{mg} \mathrm{l}^{-1}$ was found effective for the inhibition of regeneration in non-transformed shoots ( $\mathrm{Li}$ et al. 2007), suggesting the variability of antibiotic selection in each transformation system and the necessity of optimization of antibiotic selection for each plant species.

Although transgenic PnMV resistant poinsettias were produced using the Agrobacterium-mediated transformation protocol developed in the current study, the transformation frequency was fairly low (Table 5), suggesting that further improvement is required. This will be carried out in the near future.

Southern blot analysis confirmed the integration of transgenes into the poinsettia genome and detected both single- and multiple-copy integration of the transgenes among the transformants (Fig. 4). The majority (six out of eight) of the transformants showed single copy transgene integration with fragment sizes greater than that of the intact T-DNA (ca $7.5 \mathrm{~kb}$ ), indicating that the intact T-DNA was integrated into the poinsettia genome. However, the bands with sizes around 4-6 kb, smaller than that of intact T-DNA, were also found in the transgenic lines with multiple insertions (lanes 7 and 8 in Fig. 4).

According to Afolabi et al. (2004) and Zhu et al. (2006), insertion of non-intact T-DNAs were found in more than $70 \%$ of the transgenic rice lines causing $14-21 \%$ of the loci to contain only part of the T-DNA, due to T-DNA truncation. Moreover, T-DNA rearrangement is well documented in many plant species including both dicots and monocots (Deroles and Gardner 1988; Puchta et al. 1992; Azhakanandam et al. 2000; Yin and Wang 2000; Rai et al. 2007). Almost 50\% of the 27 transgenic rice lines studied showed rearrangement of T-DNA inserts according to Rai et al. (2007). Consequently, such T-DNA truncations and/or rearrangements could also possibly occur in our study causing partial T-DNA insertion. Since Agrobacetrium-mediated transformation of poinsettia has never been described before, there is no available information regarding T-DNA transfer and integration into the poinsettia genome.

The hp RNA constructs and PnMV resistance in transgenic poinsettia cv. Millenium

A number of effective approaches have been utilized to control viral diseases (Goldbach et al. 2003). Among these, coat protein-mediated and RNA silencing-based resistance have been shown to be efficient transgenic approaches to engineer virus resistance in plants (PowellAbel et al. 1986; Barker et al. 1998; Waterhouse et al. 1998; Smith et al. 2000; Domínguez et al. 2002; Lu et al. 2003). Furthermore, according to previous studies, hpRNA-induced RNA silencing is more efficient than sense- or antisense-mediated silencing (Chuang and Meyerowitz 2000).

In the current study, the establishment of Agrobacterium-mediated transformation enabled us to transform poinsettia plants with intron-containing hpRNA constructs homologous to the PnMV genome. PnMV resistant transgenic poinsettia lines showing no systemic infection were identified after mechanical inoculation as determined using the DAS-ELISA assay (Table 6). The presence of transgene-derived siRNA molecules in non-inoculated transgenic poinsettia plants carrying $\mathrm{pCP}, \mathrm{pR} 2$ and $\mathrm{pR} 3$ constructs, and the absence of these in the non-transformed control plants, indicates that the transgenes were expressed and subsequently cleaved. This data indicates that RNA silencing underlies the PnMV resistance observed in our study (Fig. 5). As mentioned previously, LMW Northern analysis included only one pR3 line (i.e.18-1) due to the limitations in the amount of RNA available for the remaining lines. Therefore, the underlying reason for lack of resistance in some of the pR3containing transformants (Table 6) needs to be clarified by further studies.

Poinsettia is a non-food, non-feed and vegetatively propagated ornamental plant. Pollen mediated transgene outflow is restricted, a significant advantage over sexually propagated plants. The combination of genetic engineering and RNA silencing technologies for the generation of virus-resistant transgenic ornamentals is therefore appealing, especially in an industry in which quality is so important. Transgenic vegetatively propagated ornamentals like PnMV resistant transgenic poinsettia are likely to be more acceptable even in areas where genetically modified crops are currently not cultivated.

In summary, we have developed an A. tumefaciensmediated transformation method for poinsettia. Using this approach, transgenic PnMV resistant transgenic lines expressing PnMV-derived hpRNA constructs were produced. Phytoplasma, the poinsettia branch-inducing factor for good branching ("free-branching") and for a compact growth habit (Lee et al. 1997), is currently being reintroduced into the transgenic poinsettias. Candidate transgenic lines with PnMV resistance and desired ornamental values will be selected for further study with the future goal of possible commercialization. The methodology developed here could facilitate the future engineering of poinsettia to meet customers' expectations for new colours and other desirable traits. 
Acknowledgments Thanks are due to Erling Fløistad, Kari Ørstad and Svein Birkenes for their practical support, CSIRO Plant Industry for providing pHannibal and pART27 vectors and to J. Kristiansen nursery for the poinsettia plants. We are grateful to Dr Sonja Klemsdal, Dr Henry Daniell and Dr Nicholas Clarke for critical reviewing of this manuscript and linguistic correction. This research was supported by the Research Council of Norway, grant: 147147/ 140.

\section{References}

Afolabi AS, Worland B, Snape JW, Vain P (2004) A large-scale study of rice plants transformed with different T-DNAs provides new insights into locus composition and T-DNA linkage configurations. Theor Appl Genet 109:815-826

Aida R, Hirose Y, Kishimoto S, Shibata M (1999) Agrobacterium tumefaciens-mediated transformation of Cyclamen persicum Mill. Plant Sci 148:1-7

Azhakanandam K, Mccabe MS, Power JB, Lowe KC, Cocking EC, Davey MR (2000) T-DNA transfer, integration, expression and inheritance in rice: effects of plant genotype and Agrobacterium super-virulence. J Plant Physiol 157:429-439

Barker H, Reavy B, McGeachy KD, Dawson S (1998) Transformation of Nicotiana benthamiana with the potato mop-top virus coat protein gene produces a novel resistance phenotype mediated by the coat protein. Mol Plant Microbe Interact 11:626-633

Baulcombe D (2005) RNA silencing. Trends Biochem Sci 30:290293

Bernstein E, Caudy AA, Hammond SM, Hannon GJ (2001) Role for a bidentate ribonuclease in the initiation step of RNA interference. Nature 409:295-296

Blystad DR, Fløistad E (2002) Transmission of Poinsettia mosaic virus. Acta Hortic 568:225-226

Bradel GB, Preil W, Jeske H (2000) Sequence analysis and genome organization of poinsettia mosaic virus (PnMV) reveal closer relationship to marafiviruses than to tymoviruses. Virology 271:289-297

Bucher E, Lohuis D, van Poppel PMJA, Geerts-Dimitriadou C, Goldbach R, Prins M (2006) Multiple virus resistance at a high frequency using a single transgene construct. J Gen Virol 87:3697-3701

Castellanos M, Power JB, Davey MR (2006) Somatic embryogenesis in red- and white-bract cultivars of poinsettia. Propag Ornam Plants 6:9-14

Chuang CF, Meyerowitz EM (2000) Specific and heritable genetic interference by double-stranded RNA in Arabidopsis thaliana. Proc Natl Acad Sci USA 97:4985-4990

Clark M, Adams A (1977) Characteristics of microplate method of enzyme-linked immunosorbent assay for the detection of plant viruses. J Gen Virol 34:475-483

Clarke JL, Klemsdal SS, Fløistad E, Hvoslef-Eide AK, Haugslien S, Moe R, Blystad DR (2006) Genetic engineering of poinsettia with the aim of enhancing its resistance to Poinsettia Mosaic Virus. Acta Hort 722:321-325

Cui ML, Ezura H (2003) Agrobacterium-mediated transformation of Nemesia strumosa Benth, a model plant for asymmetric floral development. Plant Sci 165:863-870

Deroles SC, Gardner RC (1988) Analysis of the T-DNA structure in a large number of transgenic petunias generated by Agrobacterium-mediated transformation. Plant Mol Biol 11:365-377

Deroles SC, Boase MR, Konczak I (1997) Transformation protocols for ornamental plants. In: Geneve RL, Preece JE, Merkle SA (eds) Biotechnology of ornamental plants. CAB International, Wallingford, pp 87-119
Deroles SC, Boase MR, Lee CE, Peters TA (2002) Gene transfer to plants. In: Vainstein A (ed) Breeding for ornamentals: classical and molecular approaches. Kluwer, Dordrecht, pp 156-196

Domínguez A, Hermoso de Mendoza A, Guerri J, Cambra M, Navarro L, Moreno P, Peña L (2002) Pathogen-derived resistance to Citrus tristeza virus (CTV) in transgenic Mexican lime (Citrus aurantifolia (Christ.) Swing.) plants expressing its p25 coat protein gene. Mol Breed 10:1-10

Dreher TW, Edwards MC, Gibbs AJ, Haenni AL, Hammon RD, Jupin I, Koenig R, Sabanadzovic S, About Ghanem-Sabanadzovic N, Martelli GP (2005) Family Tymoviridae. In: Fauquet CM, Mayo MA, Maniloff J, Desselberger U, Ball LA (eds) Virus taxonomy. 8th report of the international committee on the taxonomy of viruses. Elsevier Academic Press, London, pp 1067-1076

Ecke III P, Faust JE, Higgins A, Williams J (2004) The Ecke poinsettia manual. Ball Publishing, Illinois, pp 1-40

Fire A, Xu S, Montogomery MK, Kostas SA, Driver SE, Mello CC (1998) Potent and specific genetic interference by double stranded RNA in Caenorhabditis elegans. Nature 391:806-811

Fulton RW, Fulton JL (1980) Characterization of a tymo-like virus common in poinsettia. Phytopathology 70:321-324

Gleave AP (1992) A versatile binary vector system with a T-DNA organisational structure conducive to efficient integration of cloned DNA into the plant genome. Plant Mol Biol 20:12031207

Goldbach R, Bucher E, Prins M (2003) Resistance mechanisms to plant viruses: an overview. Virus Res 92:207-212

Griesbach RJ (1994) An improved method for transforming plants through electrophoresis. Plant Sci 102:81-89

Hamilton JH, Baulcombe DC (1999) A species of small antisense RNA in post-transcriptional gene silencing in plants. Science 286:950-952

Hammond J (2006) Current status of genetically modified ornamentals. Acta Hortic 722:117-127

Hammond SM, Bernstein E, Beach D, Hannon GJ (2000) An RNAdirected nuclease mediates post-transcriptional gene silencing in Drosophila cells. Nature 404:293-296

Hammond J, Hsu HT, Huang Q, Jordan R, Kamo K, Pooler M (2006) Transgenic approaches to disease resistance in ornamental crops. J Crop Improv 17:155-210

Helliwell CA, Waterhouse PM (2003) Constructs and methods for high-throughput gene silencing in plants. Methods 30:289-295

Herrera-Estrella L, Simpson J, Martínez-Trujillo M (2004) Transgenic plants. In: Peña L (ed) Transgenic plants-methods and protocols. Humana Press Inc., Totowa, pp 3-31

Hoekema A, Hirsch PR, Hooykaas PJJ (1983) A binary plant vector strategy based on separation of vir-region and T-region of the Agrobacterium tumefaciens Ti-plasmid. Nature 303:179-180

Ishida Y, Saito H, Ohta S, Hiei Y, Komari T, Kumashiro T (1996) High efficiency transformation of maize (Zea mays L.) mediated by Agrobacterium tumefaciens. Nat Biotechnol 14:745-750

Kamo K, Blowers A, Smith F, van Eck J (1995) Stable transformation of Gladiolus by particle gun bombardment of cornels. Plant Sci 110:105-111

Kamo K, Hammond J, Roh M (1997) Transformation of Gladiolus for disease resistance. J Korean Soc Hortic Sci 38:188-193

Kamo K, McElroy D, Chamberlain D (2000) Transforming embryogenic cell lines of Gladiolus with either a bar-uidA fusion or cobombardment. In Vitro Cell Dev Biol 36:182-187

Kim CK, Chung JD, Park SH, Burrell AM, Kamo KK, Byrne DH (2004) Agrobacterium tumefaciens-mediated transformation of Rosa hybrida using the green fluorescent protein (GFP) gene. Plant Cell Tissue Organ Cult 78:107-111

Kishimoto S, Aida R, Shibata M (2002) Agrobacterium-mediated transformation of Elatior Begonia (Begonia $\times$ hiemalis Fotsch). Plant Sci 162:697-703 
Lee IM, Klopmeyer M, Bartoszyk IM, Gundersen-Rindal DE, Chou TS, Thomson KL, Eisenreich R (1997) Phytoplasma induced free-branching in commercial poinsettia cultivars. Nat Biotechnol 15:178-182

Li ZN, Fang F, Liu GF, Bao MZ (2007) Stable Agrobacteriummediated genetic transformation of London plane tree (Platanus acerifolia Willd.). Plant Cell Rep 26:641-650

Lu R, Martin-Hernandez AM, Peart JR, Malcuit I, Baulcombe D (2003) Virus-induced gene silencing in plants. Methods 30:296303

Meister G, Tuschl T (2004) Mechanisms of gene silencing by doublestranded RNA. Nature 431:343-349

Metzlaff M, O’Dell M, Cluster P, Flavell R (1997) RNA-mediated RNA degradation and chalcone synthase A silencing in petunia. Cell 88:845-854

Mol JNM, Holton TA, Koes RE (1995) Floriculture: genetic engineering of commercial traits. TiBTECH 13:350-355

Murashige T, Skoog F (1962) A revised medium for rapid growth and bioassays with tobacco tissue cultures. Physiol Plant 15:495-497

Nauerbey B, Billing K, Wyndaele R (1997) Influence of the antibiotic timentin on plant regeneration compared to carbenicillin and cefotaxime in concentration suitable for elimination of Agrobacterium tumefaciens. Plant Sci 123:169-177

Osternack N, Saare-Surminski K, Preil W, Lieberie R (1999) Induction of somatic embryos, adventitious shoots and roots in hypocotyls tissue of Euphorbia pulcherrima Willd. Ex Klotzsch: comparative studies on embryogenic and organogenic competence. J Appl Bot 73:197-201

Powell-Abel P, Nelson RS, De B, Hoffmann N, Rogers SG, Fraley RT, Beachy RN (1986) Delay of disease development in transgenic plants that express the tobacco mosaic virus coat protein gene. Science 232:738-743

Preil W (1994) In vitro culture of poinsettia. In Strømme E (ed) The scientific basis of poinsettia production. Agricultural University of Norway, pp 49-55

Preil W, Beck A (1991) Somatic embryogenesis in bioreactor culture. Acta Hortic 289:179

Puchta H, Kocher S, Hohn B (1992) Extrachromosomal homologous DNA recombination in plant-cells is fast and is not affected by CpG methylation. Mol Cell Biol 12:3372-3379

Rai M, Datta K, Parkhi V, Tan J, Oliva N, Chawla HS, Datta SK (2007) Variable T-DNA linkage configuration affects inheritance of carotenogenic transgenes and carotenoid accumulation in transgenic indica rice. Plant Cell Rep 26:1221-1231

Rogers SO, Bendich AJ (1988) Extraction of DNA from plant tissues. In: Gelvin SB, Schilperoort RA (eds) Plant molecular biology manual, Kluwer, Dordrecht, pp A6:1-10

Sambrook J, Fritsch EF, Maniatis T (1989) Molecular cloning: a laboratory manual, 2nd edn. Cold Spring Harbor Laboratory Press, Cold Spring Harbor
Sanford JC, Klein TM, Wolf ED, Allen N (1987) Delivery of substances into cells and tissues using a particle bombardment process. J Part Sci Technol 5:27-37

Siepen MAD, Pohl JO, Koo BJ, Wege C, Jeske H (2005) Poinsettia latent virus is not a cryptic virus, but a natural polerovirussobemovirus hybrid. Virology 336:240-250

Smith F, Chou TS, Eisenreich R, Sanford J, Blowers A, Van Eck J (1997) Production of transgenic poinsettia. United States Patent 7119262 pp $1-36$

Smith NA, Singh SP, Wang MB, Stoutjesdijk PA, Green AG, Waterhouse PM (2000) Total silencing by intron-spliced hairpin RNAs. Nature 407:319-320

Sunikumar G, Rathore KS (2001) Transgenic cotton: factors influencing Agrobacterium-mediated transformation and regeneration. Mol Breed 8:37-52

Tabara H, Yigit E, Siomi H, Mello CC (2002) The dsRNA binding protein RDE-4 interacts with RDE-1, DCR-1, and a DExH-box helicase to direct RNAi in C. elegans. Cell 109:861-871

Teixeira da Silva JA (2004) Ornamental chrysanthemum: improvement by biotechnology. Plant Cell Tissue Organ Culture 79:1-18

Tenllado F, Llave C, Díaz-Ruíz JR (2004) RNA interference as a new biotechnological tool for the control of virus diseases in plants. Virus Res 102:85-96

Vik NI, Hvoslef-Eide AK, Gjerde H, Bakke K (2001) Stable transformation of Poinsettia via electrophoresis. Acta Hortic 560:101-103

Waterhouse PM, Graham MW, Wang MB (1998) Virus resistance and gene silencing in plants can be induced by simultaneous expression of sense and antisense RNA. Proc Natl Acad Sci USA 95:13959-13964

Wesley SV, Helliwell CA, Smith NA, Wang MB, Rouse DT, Lie Q, Gooding PS, Singh SP, Abbott D, Stoutjesdijk PA, Robinson SP, Gleave AP, Green AG, Waterhouse PM (2001) Construct design for efficient, effective and high-throughput gene silencing in plants. Plant J 27:581-590

Williams J (2005) Poinsettia production. FlowerTech 8:6-9

Wu J, Zhang X, Nie Y, Luo X (2005) High-efficiency transformation of Gossypium hirsutum embryogenic calli mediated by Agrobacterium tumefaciens and regeneration of insect-resistant plants. Plant Breed 124:142-146

Yin Z, Wang GL (2000) Evidence of multiple complex patterns of TDNA integration into the rice genome. Theor Appl Genet 100:461-470

Yoshikazu T (2004) Visual biotechnology. Blue rose realized by biotechnology. Biosci Ind 62:789-790

Zhu QH, Ramm K, Eamens AL, Dennis ES, Upadhyaya NM (2006) Transgene structures suggest that multiple mechanisms are involved in T-DNA integration in plants. Plant Sci 171:308-322

Zuker A, Tzfira T, Vainstein A (1998) Genetic engineering for cutflower improvement. Biotechnol Adv 16:33-79 